Review

\title{
One Step Formation of Propene from Ethene or Ethanol through Metathesis on Nickel Ion-loaded Silica
}

\author{
Masakazu Iwamoto \\ Chemical Resources Laboratory, Tokyo Institute of Technology, 4259-R1-5 Nagatsuta, Midori-ku, \\ Yokohama 226-8503, Japan; E-Mail: iwamoto@res.titech.ac.jp; Tel.: +81-45-924-5225; \\ Fax: $+81-45-924-5228$
}

Received: 30 June 2011; in revised form: 4 August 2011 / Accepted: 5 September 2011 /

Published: 13 September 2011

\begin{abstract}
Increased propene production is presently one of the most significant objectives in petroleum chemistry. Especially the one-step conversion of ethene to propene (ETP reaction, $3 \mathrm{C}_{2} \mathrm{H}_{4} \rightarrow 2 \mathrm{C}_{3} \mathrm{H}_{6}$ ) is the most desired process. In our efforts, nickel ion-loaded mesoporous silica could turn a new type of ETP reaction into reality. The one-step conversion of ethene was $68 \%$ and the propene selectivity was $48 \%$ in a continuous gas-flow system at $673 \mathrm{~K}$ and atmospheric pressure. The reactivity of lower olefins and the dependences of the ETP reaction on the contact time and the partial pressure of ethene were consistent with a reaction mechanism involving dimerization of ethene to 1-butene, isomerization of 1-butene to 2-butene, and metathesis of 2-butene and ethene to yield propene. The reaction was then expanded to an ethanol-to-propene reaction on the same catalyst, in which two possible reaction routes are suggested to form ethene from ethanol. The catalysts were characterized mainly by EXAFS and TPR techniques. The local structures of the nickel species active for the ETP reaction were very similar to that of layered nickel silicate, while those on the inert catalysts were the same as that of $\mathrm{NiO}$ particles.
\end{abstract}

Keywords: ethene; ethanol; propene; metathesis; nickel; mesoporous silica

\section{Introduction}

The mainstay of petrochemical industries in the world is still ethene $\left(\mathrm{C} 2^{\overline{ }}\right)$, while the need for propene $\left(\mathrm{C}^{-}\right)$is rapidly increasing due to the increasing demand of polypropene, propene oxide, etc. 
$[1,2]$. This trend has led to the need for the conversion of $\mathrm{C} 2{ }^{=}$to $\mathrm{C} 3^{=}$(ETP reaction) or of increased production of $\mathrm{C}^{2}$. Three kinds of measures are applied or suggested for this problem. First is the so-called mild-cracking: however, the increment of $\mathrm{C}^{-}{ }^{-}$in this case is limited due to narrow range of applicable reaction conditions. Second is metathesis of $\mathrm{C} 2^{-}$and butenes $\left(\mathrm{C}^{-}\right)$to form $\mathrm{C} 3^{=}$, for instance, the $\mathrm{ABB}$ Lummus process [3]. Its disadvantage is the necessity for equimolar amounts of $\mathrm{C}_{2}=$ and $\mathrm{C}^{=}$. Third is direct ETP conversion without any addition of other hydrocarbons. This would be the most desirable route, but no good catalyst for the reaction has been found so far. Supported molybdenum [4] and tungsten oxide [5] have been reported as possible catalysts, but their activity was so low as to be observed only in a closed recirculation system. On the other hand, various zeolites have been employed as catalysts for this reaction [6,7]. The reaction involves oligomerization/ polymerization of lower olefins, subsequent decomposition to yield $\mathrm{C} 3{ }^{=}$or other species on the strong acid sites of the zeolites, and selective evolution of $\mathrm{C} 3^{-}$due to the shape-selectivity of zeolite pores. This process has the limitations of selectivity due to the shape selectivity and of catalyst lifetime owing to coke formation. The present objective is the selective formation of $\mathrm{C} 3^{=}$without the shape-selectivity.

The catalytic activity of $\mathrm{Ni}$ ion for the dimerization or oligomerization of olefins was found 50 years ago and has been widely studied [8]. In the case of heterogeneous catalysis, Ozaki et al. [9-12] reported the high catalytic activity of $\mathrm{Ni} / \mathrm{SiO}_{2}$ for the dimerization, though severe deactivation during the reaction prevented it from being applied in the practical process. They also found that acidic supports were effective for enhancement of the catalytic activity of nickel. A similar catalytic activity was also confirmed on various Ni-zeolites [13,14] or on Ni supported on MCM-41 [15] in a closed recirculation system. Since we had already found the acidic properties of silica MCM-41 [16-23], we tried the dimerization of $\mathrm{C} 2{ }^{=}$to $\mathrm{C} 4^{=}$. During the study a subsequent reaction of the produced $\mathrm{C} 4{ }^{=}$and unreacted $\mathrm{C} 2{ }^{-}$to yield $\mathrm{C} 3^{-}$was uncovered. As a result we found that $\mathrm{Ni}$ ion-loaded mesoporous silica (Ni-MCM-41, abbreviated as Ni-M41) was highly active in the ETP transformation.

On the other hand the use of bio-ethanol $(\mathrm{bEtOH})$ as an additive for automobile fuels has increased rapidly all over the World. This is one way of using renewable resources to suppress carbon dioxide emissions, while another challenge is the conversion of bEtOH into various olefins and their use for production of chemicals and polymers [1,2,24-48]. The latter would be very significant for the longterm fixation of carbon dioxide. Many efforts have therefore devoted to the development of systems for converting bEtOH to $\mathrm{C} 2{ }^{*}$ and other lower olefins. In particular conversion to $\mathrm{C}^{-}{ }^{*}$ is desirable due to the greater demand for $\mathrm{C} 3=$ derivatives $[1,2]$.

Catalytic conversions of EtOH on zeolites [7,24-35] and metal oxides [36-48] have been widely studied. On zeolites, the activity and selectivity reported so far in many studies were insufficient. The major weakness is again catalyst deactivation [7,24-35]. EtOH can also react on metal oxide surfaces, to give various chemicals. Acid sites are widely recognized to lead to dehydration of EtOH, giving $\mathrm{C}^{2}$, while basic sites lead to dehydrogenation to yield acetaldehyde (AAD) [36-48]. As a result, many kinds of products, for example aldehydes, ketones, $\mathrm{C} 2^{-}$, and $\mathrm{C} 4^{=}$, were observed on oxide catalysts. In this catalysis $\mathrm{C}_{4}{ }^{*}$ and other higher olefins were produced by oligomerization of $\mathrm{C}_{2}{ }^{*}$, but as far as we are aware, significant $\mathrm{C}^{-}$production on oxide catalysts has not been reported. The results for the ETP reaction on Ni-M41 leaded us to apply the same catalyst for the conversion of EtOH to $\mathrm{C}^{-}{ }^{-}$since M41 is active for the dehydration of $\mathrm{EtOH}$ to yield $\mathrm{C} 2^{=}[49,50]$. This was first confirmed by us [51-54] and 
subsequently by Sugiyama et al. [55]. The pore diameters of M41 are usually 1.5-5.0 nm, and therefore the product distribution on the catalysts is not controlled by shape selectivity. The reaction mechanism/pathways are of interest, and will be suggested here. In the final part of this review the catalysts were characterized and the correlation of activities with catalyst preparation methods were also discussed.

\section{Results and Discussion}

\subsection{Conversion of Ethene to Propene on Ni-M41 Catalysts}

The reactions on Ni-M41 were examined as a function of reaction temperature. The dimerization of $\mathrm{C}{ }^{=}$to $\mathrm{C} 4{ }^{=}$mainly proceeded at $573 \mathrm{~K}$. When $0.5 \mathrm{~g}$ of $\mathrm{Ni}-\mathrm{M} 41(\mathrm{Si} / \mathrm{Ni}=15)$ was used, the degrees of conversion of $\mathrm{C}_{2}{ }^{-}$and the selectivity to $\mathrm{C}^{*}$ reached 43 and $93 \%$, respectively. The production ratio of 1-, trans-2-, and cis-2-butene was 0.5:1.0:0.3. At 673-723 K the major products were $\mathrm{C} 3{ }^{=}$and $\mathrm{C} 4=$ The respective conversion levels were dependent on the partial pressure of $\mathrm{C}_{2}{ }^{-}$and the contact time, as shown later. Hexenes, the product of $\mathrm{C}^{-}$trimerization, were observed at the wide temperature range but the yields were always less than $5 \%$.

When silica gel was used as the support instead of M41 and nickel ion was loaded with the usual impregnation method, both the conversion level and the selectivity of $\mathrm{C} 3=$ were very poor. In addition, no $\mathrm{C}^{=}$was produced on M41 alone, indicating the necessity of nickel ion for the reaction. It follows that the coexistence of nickel ion and mesoporous structure of the support make the $\mathrm{C} 3^{=}$formation possible. The catalyst was continuously used at $673 \mathrm{~K}$ for $10 \mathrm{~h}$ to determine the possible deactivation. Small changes in the catalytic activity for the formation of $\mathrm{C} 3^{-}$were observed in the initial stage, but the activity became stable within $2 \mathrm{~h}$ and no deactivation was found during the $10 \mathrm{~h}$ experiment. The XRD patterns and the surface areas of Ni-M41 remained unchanged after the catalytic runs. Thus the stability of the present Ni-M41 catalysts under the present reaction conditions could be confirmed.

The correlations between the product distribution and the reaction conditions were then investigated. In the range $\mathrm{P}_{\mathrm{C}_{2} \mathrm{H}_{4}}=10-50 \%$, the conversion levels of $\mathrm{C}_{2}{ }^{-}$and to $\mathrm{C}^{-}$and $\mathrm{C}^{=}$increased monotonously with increasing $\mathrm{P}_{\mathrm{C}_{2} \mathrm{H}_{4}}$. At $\mathrm{P}_{\mathrm{C}_{2} \mathrm{H}_{4}}=49.7 \%$, the respective conversions to $\mathrm{C} 3, \mathrm{C} 4$, and $\mathrm{C} 6$ olefins were 33,29 , and $6 \%$ on $0.3 \mathrm{~g}$ of Ni-M41(20). The carbon balance was $99.8 \%$ in each experiment, which indicates almost no production of "unknown products". The degree of conversion to $\mathrm{C} 3^{=}, 33 \%$, appears to rather small but it should be noted that the concentration of unreacted $\mathrm{C} 2^{-}$was about $34 \%$ under the present conditions and the ratio of $\mathrm{C}{ }^{-} / \mathrm{C} 2^{=}=33 / 34$ in carbon basis would be sufficiently great.

Figure 1 shows the change in product distribution as a function of the weight of Ni-M41 employed, i.e., the contact time dependence of the reaction. Clearly, longer contact times resulted in greater conversion of $\mathrm{C}_{2}{ }^{*}$ and better selectivity for $\mathrm{C} 3^{*}$, while the selectivity for $\mathrm{C} 4{ }^{-}$decreased and that of hexenes was almost constant. Propene is indeed the secondary product in the consecutive reaction of $\mathrm{C}_{2}{ }^{=}$on Ni-M41. At $0.5 \mathrm{~g}$ of Ni-M41(43), the degrees of $\mathrm{C}{ }^{-}$conversion and $\mathrm{C}{ }^{=}$selectivity were 55 and $54 \%$, respectively. 
Figure 1. Change in ethene conversion and product distribution at $673 \mathrm{~K}$ with weight of Ni-M41(43). The codes C2-C6 mean ethene, propene, butenes, and hexenes.

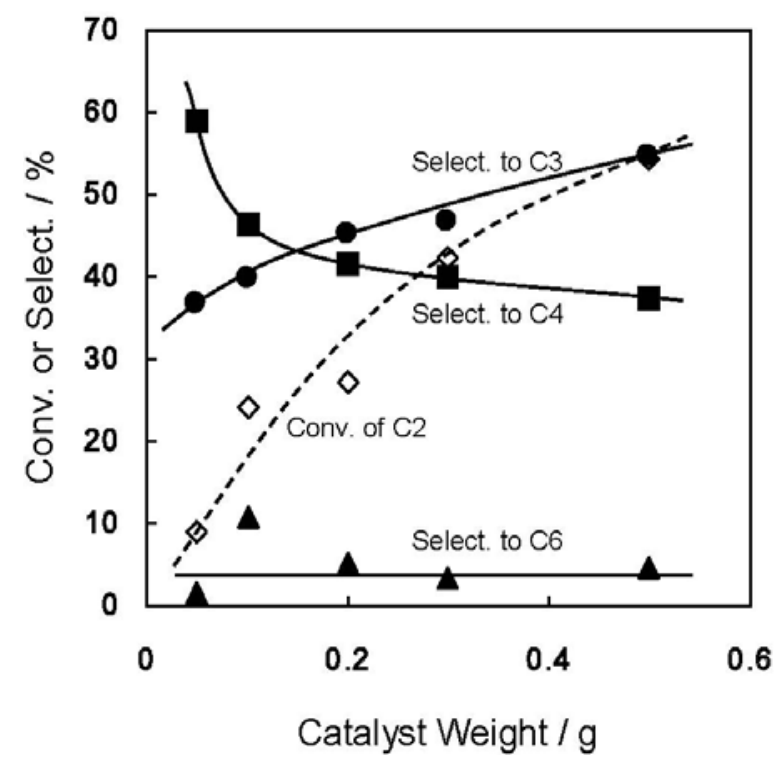

The reaction of $\mathrm{C}_{2}=$ and 1-butene was then studied to clarify the mechanism of the $\mathrm{C}^{=}$formation and the results are summarized in Figure $2 \mathrm{~A}$. One can recognize the selective formation of $\mathrm{C}^{=}$on $\mathrm{Ni}-\mathrm{M} 41$ at the temperature of $623 \mathrm{~K}$ and higher. The increment in the amount of $\mathrm{C}^{-}{ }^{=}$at $523-573 \mathrm{~K}$ is due to the dimerization of $\mathrm{C}_{2}{ }^{=}$. The selective production of $\mathrm{C}^{=}$would indicate the progress of the metathesis reaction on this catalytic system. To confirm the reaction pathway in more detail, we examined two kinds of reactions. The first was the reaction of 1-hexene. When 1-hexene was introduced onto the Ni-M41 catalyst, methane, $\mathrm{C} 2{ }^{-}, \mathrm{C} 4^{*}$, and pentenes were produced, besides $\mathrm{C} 3^{=}$, indicating the random scission of carbon-carbon bonds of 1-hexene. This indicates little possibility that $\mathrm{C}^{2}{ }^{-}$and 1-butene first afford hexenes and the resulting hexenes homolytically decompose to give $\mathrm{C} 3{ }^{=}$ selectively in the experiments of Figure 2A. The second reaction examined was the retro-metathesis reaction. Namely the reaction of $\mathrm{C}{ }^{=}$on Ni-M41 was investigated and shown to readily proceeded to yield equimolar $\mathrm{C}_{2}{ }^{-}$and $\mathrm{C}_{4}{ }^{-}$as shown in Figure $2 \mathrm{~B}$. The amounts of by-products were always small. It was further confirmed in separate experiments that the parent M41 was not active for the reaction of $\mathrm{C}^{=}{ }^{-}$and $\mathrm{C} 4{ }^{=}$. All of the results therefore strongly suggest the metathesis reaction on Ni-M41 and that the active center for the catalysis would be nickel ion.

Although at present we cannot preclude the possibility of a decomposition mechanism of higher olefins because other types of reaction mechanisms have been suggested on $\mathrm{Cr}$ [56] or $\mathrm{Zr}$ [57], we believe that the metathesis mechanism (Figure 3 ) is the most plausible reaction mechanism for the $\mathrm{C}^{2}=$ formation on Ni-M41. That is, at first two $\mathrm{C} 2{ }^{-}$molecules dimerize to give 1-butene on $\mathrm{Ni}$, and the resulting 1-butene then isomerizes to 2-butene on the acid sites of M41, and finally the metathesis of the produced 2-butene with unreacted $\mathrm{C} 2{ }^{-}$proceeds to form $\mathrm{C} 3{ }^{-}$on Ni. The acidic properties of M41 silica were already been reported by us [16-20] and the other research groups [15,21-23] and the isomerization of 1-butene to 2-C4 $4^{=}$, a typical acid-catalyzed reaction, was indeed confirmed on silica M41 [15]. 
Figure 2. Metathesis reaction of ethene and 1-butene $\left(A, \mathrm{P}_{\mathrm{C}_{2} \mathrm{H}_{4}}=\mathrm{P}_{\mathrm{C}_{4} \mathrm{H}_{8}}=5 \%\right)$ or propene $\left(\mathbf{B}, \mathrm{P}_{\mathrm{C}_{3} \mathrm{H}_{6}}=10 \%\right)$ on $0.3 \mathrm{~g}$ of Ni-M41(15). The codes $\mathrm{C} 2-\mathrm{C} 6$ mean ethene, propene, butenes, pentenes, and hexenes. In Figure 2B, the left vertical axis is the amount of propene and the right those of the products.

(A)

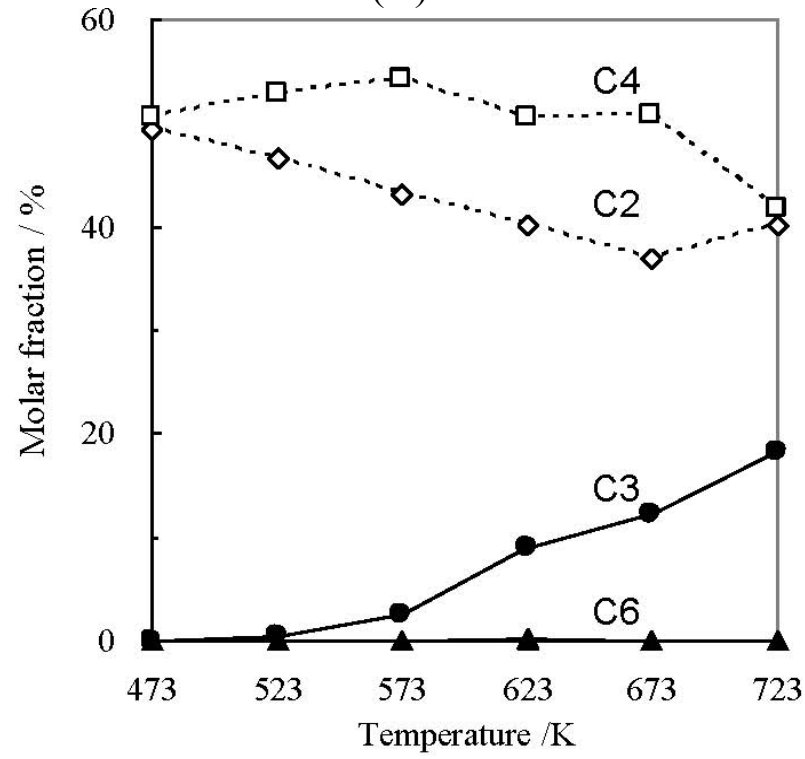

(B)

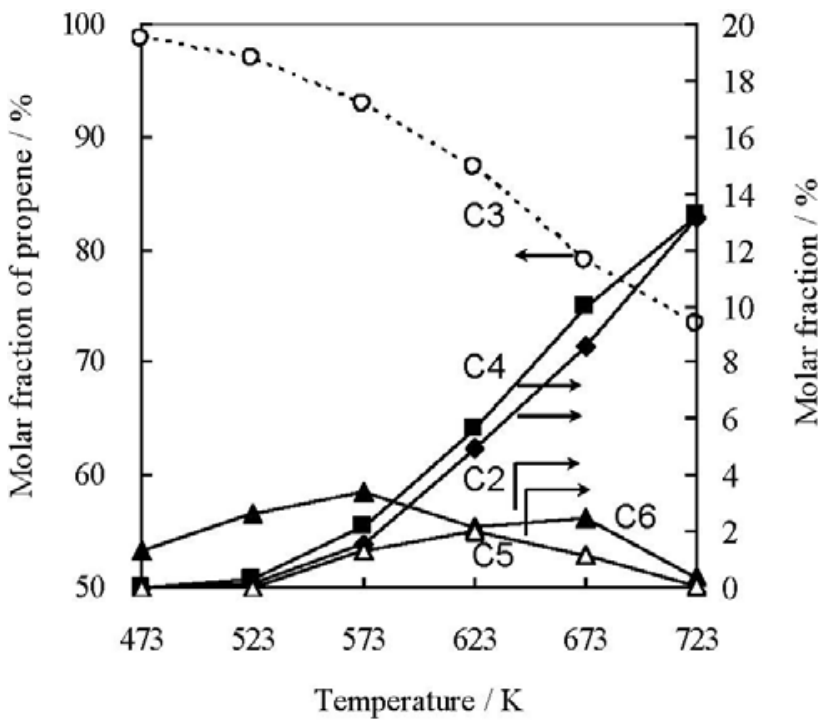

Figure 3. Proposed reaction mechanism for the conversion of ethene to propene on Nickel ion-loaded MCM-41.

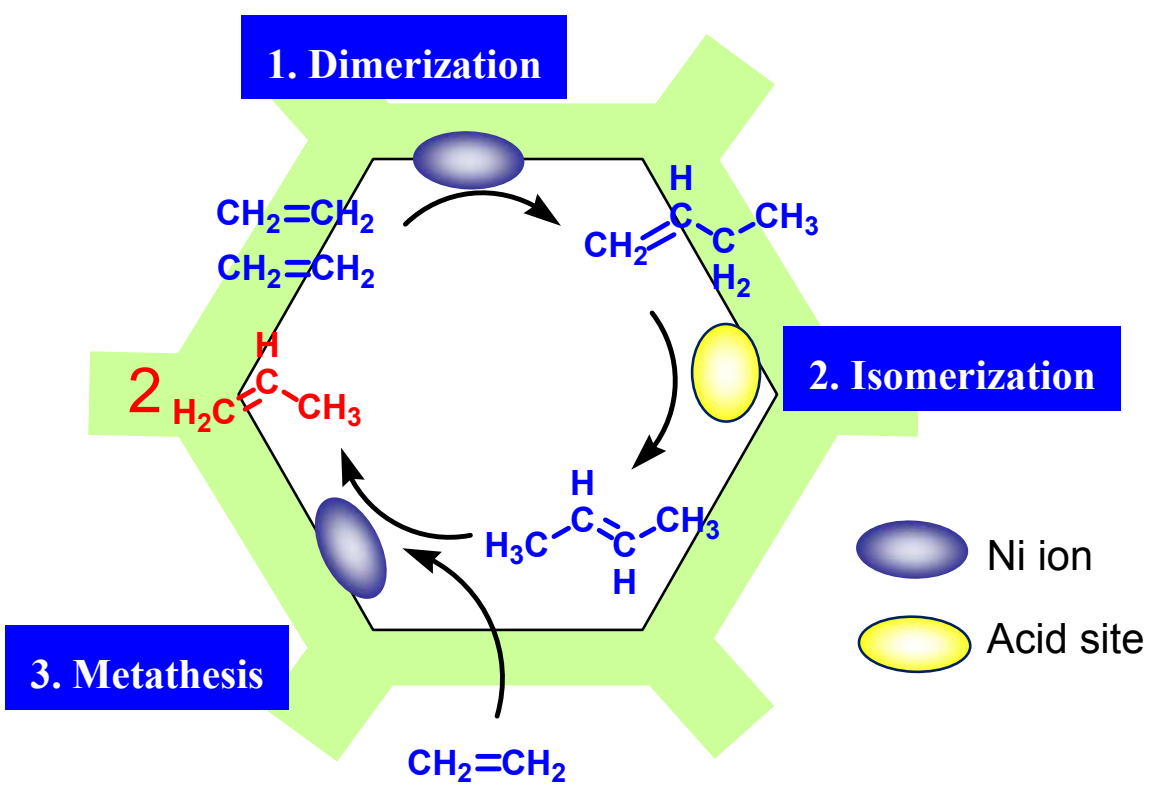

As has been summarized by Grubbs [58,59] and Arpe [1], the metathesis reaction is one of the most important organic reactions. Despite world-wide study it is well known that the catalytically active species for the reaction are confined to $\mathrm{Mo}, \mathrm{W}, \mathrm{Ru}$, and $\mathrm{Re}$. The present results might suggest that nickel-ion loaded mesoporous silica is also active for the metathesis of $\mathrm{C}^{-}{ }^{-}$and $\mathrm{C} 2{ }^{-}$to yield $\mathrm{C} 3^{-}$in the gas-phase flow reaction. Mori et al. [60] suggested the possibility of metathesis on a $\mathrm{Ni}(0)$ complex in their discussion, while Baker et al. [61] concluded no progress of a metathesis reaction on $\mathrm{Ni}$ 
complexes. At the moment, no reports claim nickel ion as a catalytically active species for metathesis. It is noteworthy that the surface density of $\mathrm{Ni}$ is approximately $0.5 \mathrm{Ni} / \mathrm{nm}^{2}$ in the case of Ni-M41(20) on the assumption of the even distribution of nickel on the surface. The valence of nickel ion in the mesoporous silica were not studied here. There are two possibilities for the redox cycles of nickel species, Ni(I)-Ni(III) and Ni(0)-Ni(II). In Section 3.3 the TPR experiments will indicate the difficult reduction of nickel species loaded on $\mathrm{M} 41$ to $\mathrm{Ni}(0)$, which would be one important factor for generation of the catalytic activity. Therefore we speculate that the $\mathrm{Ni}(\mathrm{I})-\mathrm{Ni}$ (III) system would be the possible redox cycle for the metathesis reaction. The stability of Ni(I) in the zeolites [62-64] and mesoporous materials [65,66] support the speculation that $\mathrm{Ni}(\mathrm{I})$ is an active center and a $\mathrm{Ni}(\mathrm{III})$ carbene is produced as an intermediate.

Finally the effectiveness of other metal ions for this reaction is briefly introduced here. The conversion levels of $\mathrm{C}^{-}$on $\mathrm{Al}$ (22), Ti (30), V (22), Cr (43), Mn (20), Fe (25), Co (16), Cu (37), Zn (28), Zr (23), Mo (30), or W (30) loaded M41 were all 5\% or less at $673 \mathrm{~K}$, and most of the products were "unknown products". It should be noted, however, that the gas-phase dimerization-isomerization-metathesis of $\mathrm{C}_{2}{ }^{=}$on tungsten catalysts was independently reported by Basset et al. [67] and the others [68]. The difference clearly results from the discrepancy of reaction conditions. Ru or Re loaded MCM-41 were prepared separately through the conventional impregnation method and employed as the catalyst for the present reaction at $673 \mathrm{~K}$ because of its high activity reported at lower temperatures, but no activity for the $3 \mathrm{C}_{2}{ }^{=} \rightarrow 2 \mathrm{C}_{3}{ }^{=}$reaction was observed in our experiments. This would be due to the lack of activity of $\mathrm{Ru}$ or $\mathrm{Re}$ for the dimerization of $\mathrm{C}_{2}{ }^{=}$and the difference of the reaction temperature applied. Clearly only nickel ion shows the unique activity for the ETP conversion in the gas-phase reaction at $673 \mathrm{~K}$. The reason for the specific activity of nickel ion on MCM-41 would be a target of the future work.

\subsection{Reaction of Ethanol on Ni-MCM-41}

The influence of temperature on EtOH conversion over Ni-M41 is summarized in Figure 4. Many kinds of products were formed in addition to $\mathrm{C} 2{ }^{=}$. Diethyl ether (DEE) was mainly obtained at around $523 \mathrm{~K}$. DEE has been reported earlier as an intermediate compound in the dehydration, decomposing to yield $\mathrm{EtOH}$ and $\mathrm{C}_{2}{ }^{=}$at higher temperatures $[49,50]$. The $\mathrm{C}^{-}{ }^{-}$yield increased sharply at $573 \mathrm{~K}$, and reached ca. $70 \%$ at $623 \mathrm{~K}$ or above. The $\mathrm{C}^{=}$yield reached a maximum at $623 \mathrm{~K}$, while maxima in $\mathrm{C}^{=}$ yield occurred at 673 and $723 \mathrm{~K}$. Notably, AAD was formed at 573-723 K, although not in large amounts, which will be discussed later.

The stability of Ni-M41 was examined at $673 \mathrm{~K}$. The catalytic activity did not change during $20 \mathrm{~h}$ of continuous time on stream. In addition, the carbon-based mass balances were always ca. 100\%, within the experimental errors. The results demonstrate the stable catalytic activity of Ni-M41. However, there is the possibility that losses of catalytic activity could not be determined under these conditions because the catalytic activity of Ni-M41 was very high, as will be revealed in a following paragraph, and the conversion levels of EtOH were always ca. $100 \%$. The yields of $\mathrm{C}^{2}=\mathrm{C} 3={ }^{=}, \mathrm{C} 4=$, and AAD were $67,16,5$, and $7 \%$, respectively. The values should be compared with those of the reaction of $\mathrm{C}_{2}{ }^{=}$on the same catalyst reported previously (see Section 3.1). At $673 \mathrm{~K}$ and $P_{\mathrm{C} 2=}=10 \mathrm{vol} \%$, the $\mathrm{C} 2{ }^{=}$conversion and selectivity to $\mathrm{C}^{-}{ }^{-}$and $\mathrm{C} 4{ }^{-}$were reported to be 42,47 , and $40 \%$, respectively 
$[49,50]$. Clearly, the product distribution for the $\mathrm{EtOH}$ reaction is different from that of the $\mathrm{C}^{=}$ reaction. This difference might result from a change in active sites through adsorption of EtOH, AAD, or intermediates, or from a difference in reaction mechanism. The dependence on the partial pressure of EtOH was also studied at $P_{\mathrm{EtOH}}=3.0-13.2 \mathrm{kPa}$ and a space velocity (SV) of $1,000 \mathrm{~h}^{-1}$. Little dependence of $\mathrm{C}^{-}$formation on $P_{\mathrm{EtOH}}$ was observed under the present conditions, probably indicating strong adsorption of $\mathrm{EtOH}$ on the active sites.

Figure 4. Reaction temperature dependence of conversion of EtOH on a Ni-M41(23) catalyst. Catalyst wt. $0.2 \mathrm{~g}$, Flow rate $10 \mathrm{~mL} / \mathrm{min}, \mathrm{P}_{\mathrm{EtOH}} 5.6 \mathrm{kPa}\left(\mathrm{N}_{2}\right.$ balance). Conversion of $\mathrm{EtOH}$ (closed circle), yield of $\mathrm{C}^{=}$(open circle), $\mathrm{C}^{=}$(open triangle), $\mathrm{C} 4{ }^{=}$(open square), DEE (closed triangle), and AAD (closed square).

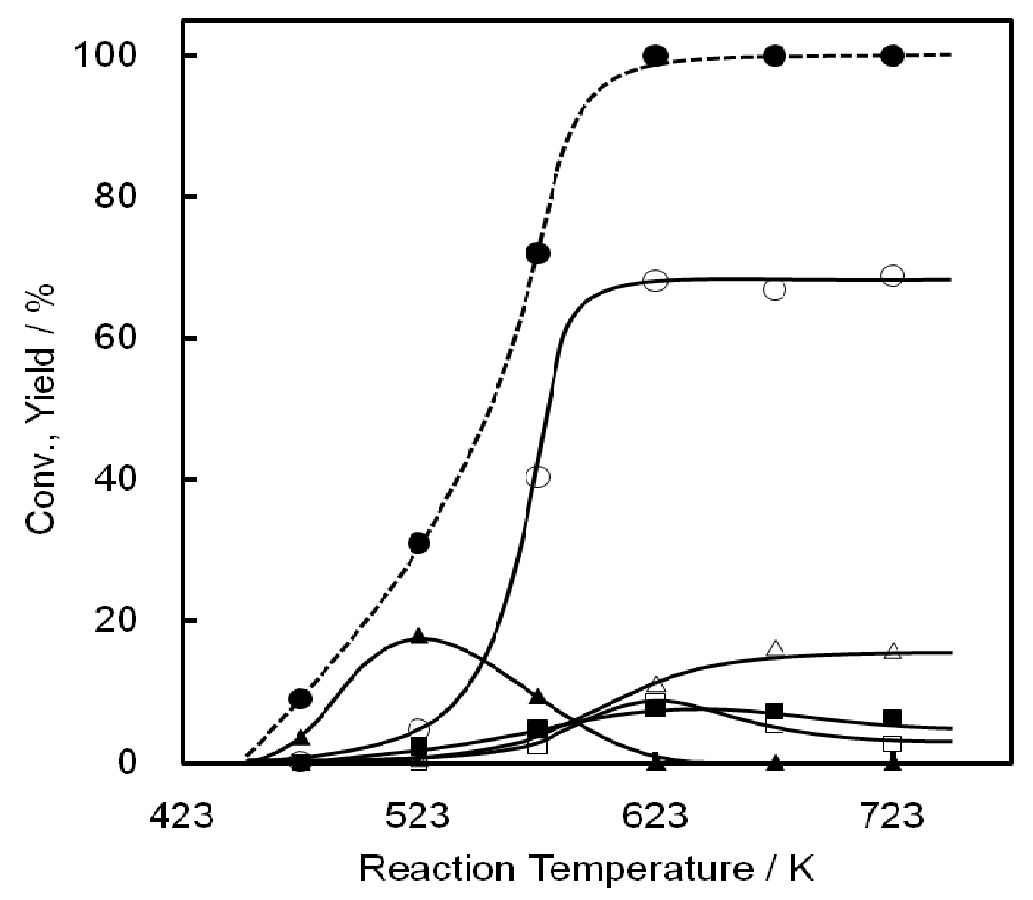

A similar reaction of EtOH on proton-exchanged ZSM-5 zeolites was reported to be retarded in the presence of water vapor [7,24-29,35], so the effect of water addition on the catalytic activity of Ni-M41 was studied here. When EtOH/water ratios were varied in the range 100:0-75:25 (w/w), the EtOH conversion levels and product distribution changed only a little. This result is very significant for the application of the present system to bEtOH conversion, because coarsely distilled bEtOH usually contains $5-10$ vol \% water.

The product distribution as a function of space velocity was studied on Ni-M41 at $673 \mathrm{~K}$. The dependence is summarized in Figure 5. At SV $=70,000 \mathrm{~h}^{-1}$ the conversion level of EtOH was ca. 50\%, but at 20,000 or below it increased to $95 \%$ or more. It follows that Ni-M41 is very active for the catalytic conversion of EtOH. 
Figure 5. Conversion of EtOH on Ni-M41(23-28) as a function of space velocity. Catalyst wt. $0.05-0.4 \mathrm{~g}$, Flow rate $10-300 \mathrm{~mL} / \mathrm{min}, \mathrm{P}_{\mathrm{EtOH}} 5.6 \mathrm{kPa}\left(\mathrm{N}_{2}\right.$ balance). Conversion of $\mathrm{EtOH}$ (closed circle), selectivity of $\mathrm{C}^{=}$(open circle), $\mathrm{C} 3{ }^{=}$(open triangle), $\mathrm{C}^{=}$(open square), DEE (closed triangle), and AAD (closed square).

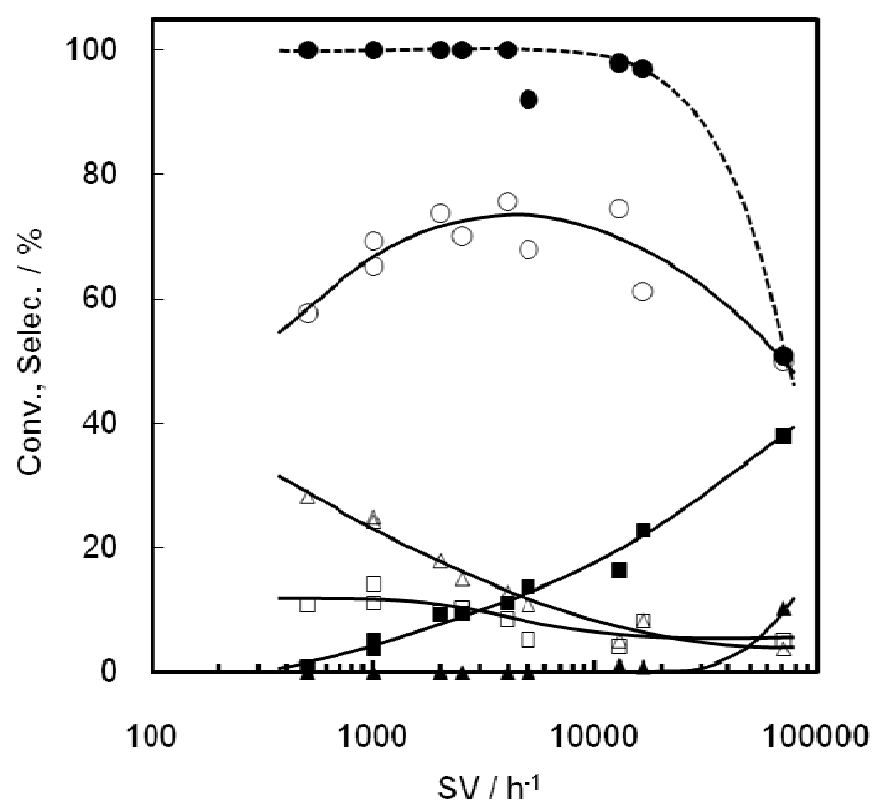

The product distribution depends strongly on the space velocity. At higher SVs (in the 10,000$100,000 \mathrm{~h}^{-1}$ region) AAD is produced in large amounts, and the amount decreases monotonically with decreasing SV. DEE was also produced and its formation showed a behavior similar to that of AAD, although the amount formed was very small. $\mathrm{C} 2{ }^{-}$was always a major product in the reaction, and its yield reached a maximum at $2,000-3,000 \mathrm{~h}^{-1}$. On the other hand the yields of $\mathrm{C}^{=}{ }^{=}$and $\mathrm{C}^{=}$gradually increased with decreasing SV, indicating that these compounds are products from the terminal phases of consecutive reactions. On the basis of the above results, we suggest the following reaction pathways to form $\mathrm{C}^{2}$ via $\mathrm{DEE}$ and $\mathrm{C} 2{ }^{=}$as intermediates:

$$
\begin{gathered}
2 \mathrm{CH}_{3} \mathrm{CH}_{2} \mathrm{OH}(\mathrm{EtOH}) \rightarrow \mathrm{CH}_{3} \mathrm{CH}_{2} \mathrm{OCH}_{2} \mathrm{CH}_{3}(\mathrm{DEE})+\mathrm{H}_{2} \mathrm{O} \\
\mathrm{CH}_{3} \mathrm{CH}_{2} \mathrm{OCH}_{2} \mathrm{CH}_{3} \rightarrow \mathrm{CH}_{2}=\mathrm{CH}_{2}\left(\mathrm{Cl}^{=}\right)+\mathrm{CH}_{3} \mathrm{CH}_{2} \mathrm{OH} \\
2 \mathrm{CH}_{2}=\mathrm{CH}_{2} \rightarrow \mathrm{CH}_{2}=\mathrm{CHCH}_{2} \mathrm{CH}_{3}\left(\mathrm{C}^{=}\right) \\
\mathrm{CH}_{2}=\mathrm{CHCH}_{2} \mathrm{CH}_{3} \rightarrow \mathrm{CH}_{3} \mathrm{CH}=\mathrm{CHCH}_{3}\left(\mathrm{CH}^{-}\right) \\
\mathrm{CH}_{3} \mathrm{CH}=\mathrm{CHCH}_{3}+\mathrm{CH}_{2}=\mathrm{CH}_{2} \rightarrow 2 \mathrm{CH}_{2}=\mathrm{CHCH}_{3}\left(\mathrm{C}^{-}\right)
\end{gathered}
$$

Although the formation of DEE from $\mathrm{EtOH}$ and the subsequent decomposition to yield $\mathrm{C}^{2}=$ and $\mathrm{EtOH}$ on a M41 catalyst was already reported [49], the progress was here confirmed this separately. In Figure 6 DEE was employed as a substrate and the product distribution was examined as a function of reaction temperature. At $523 \mathrm{~K}$ the conversion of DEE to $\mathrm{EtOH}$ and $\mathrm{C}_{2}=$ was again confirmed. At $573 \mathrm{~K}$ the major products were $\mathrm{C} 2{ }^{-}$and $\mathrm{C} 4{ }^{-}$and a small amount of $\mathrm{C} 3{ }^{-}$was produced. At $673 \mathrm{~K}$ the produced $\mathrm{C} 2{ }^{=}$and $\mathrm{C}^{-}{ }^{+}$were converted to $\mathrm{C} 3{ }^{-}$through metathesis, as reported previously $[49,50]$. 
Figure 6. Change in conversion of DEE on Ni-M41(23) with reaction temperature and time. Catalyst wt. $0.2 \mathrm{~g}$, Flow rate $10 \mathrm{~mL} / \mathrm{min}, \mathrm{P}_{\mathrm{DEE}} 5.1 \mathrm{kPa}\left(\mathrm{N}_{2}\right.$ balance). Conversion of $\mathrm{DEE}$ (closed triangle), yield of $\mathrm{C}^{=}$(open circle), $\mathrm{C} 3^{=}$(open triangle), $\mathrm{C} 4{ }^{=}$(open square), EtOH (closed circle), and AAD (closed square).

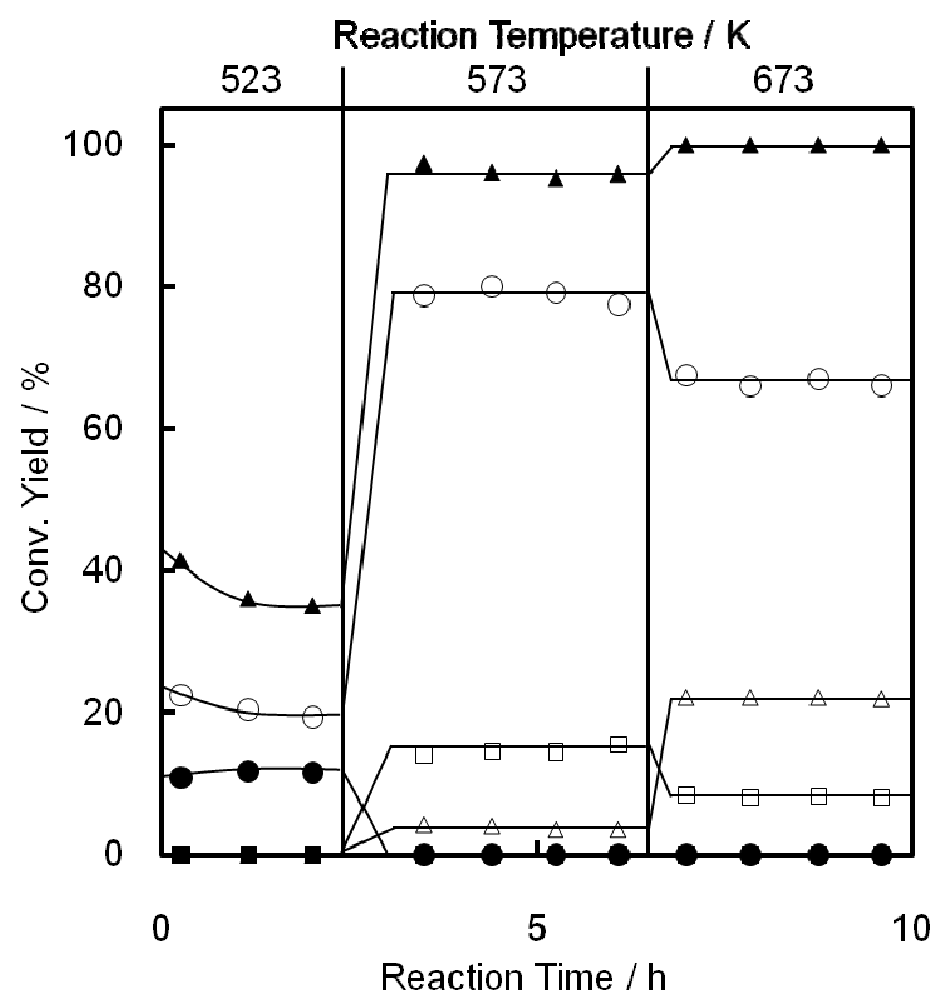

There was one more important question in the results of Figure 5: the meaning of the increment in $\mathrm{AAD}$ at higher $\mathrm{SV}$ values. The results showed that $\mathrm{AAD}$ was an intermediate to form $\mathrm{C} 2{ }^{=}$, although the reaction was never suggested. The following reaction is widely accepted to proceed on various catalysts:

$$
\mathrm{CH}_{3} \mathrm{CH}_{2} \mathrm{OH} \rightarrow \mathrm{CH}_{3} \mathrm{CHO}+\mathrm{H}_{2}
$$

The possibility that mixtures of AAD and hydrogen really give $\mathrm{C2}^{-}$is examined here. An equimolar mixture of AAD and $\mathrm{H}_{2}\left(6 \mathrm{kPa}\right.$, respectively, $\mathrm{N}_{2}$ balance $)$ was introduced onto the Ni-M41 catalyst at 573-773 K and a SV of $4,600 \mathrm{~h}^{-1}$, but no reaction except for condensation of AAD and low levels of methane and $\mathrm{C}_{2}=$ formation $(2-3 \%$, respectively) was observed. The possibility that the reverse reaction of Equation (6) and subsequent dehydration of resultant $\mathrm{EtOH}$ might lead to the formation of $\mathrm{C}^{-}{ }^{-}$is therefore ruled out. Next, an equimolar mixture of EtOH and AAD (5 $\mathrm{kPa}$ respectively, $\mathrm{N}_{2}$ balance) was introduced onto the Ni-M41 catalyst at $673 \mathrm{~K}$ and a SV of $990 \mathrm{~h}^{-1}$. The conversion levels of $\mathrm{EtOH}$ and $\mathrm{AAD}$ were 100 and $65 \%$ and the selectivities to $\mathrm{C}^{-}, \mathrm{C} 3^{-}$, and $\mathrm{C}^{-}{ }^{=}$were 61,15 , and $12 \%$, respectively. The selectivity was very similar to that observed in Figures 4 and 5. AAD can be converted into $\mathrm{C}_{2}{ }^{-}$in the presence of EtOH and Equations (3-5) subsequently proceed in this reaction system.

In the experiments of Figure 5 trace amounts of ethyl acetate (ETA) were observed, although the amount was not quantified. The following reactions could be suggested for the formation of $\mathrm{C} 2^{-}$from $\mathrm{AAD}$ and $\mathrm{EtOH}$ : 


$$
\begin{gathered}
\mathrm{CH}_{3} \mathrm{CHO}+\mathrm{CH}_{3} \mathrm{CH}_{2} \mathrm{OH} \rightarrow \mathrm{CH}_{3} \mathrm{COOCH}_{2} \mathrm{CH}_{3}(\mathrm{ETA})+\mathrm{H}_{2} \\
2 \mathrm{CH}_{3} \mathrm{CHO} \rightarrow \mathrm{CH}_{3} \mathrm{COOCH}_{2} \mathrm{CH}_{3}(\mathrm{ETA}) \\
\mathrm{CH}_{3} \mathrm{COOCH}_{2} \mathrm{CH}_{3} \rightarrow \mathrm{CH}_{3} \mathrm{COOH}+\mathrm{CH}_{2}=\mathrm{CH}_{2} \\
\mathrm{CH}_{3} \mathrm{COOCH} \mathrm{CH}_{3}+\mathrm{H}_{2} \mathrm{O} \rightarrow \mathrm{CH}_{3} \mathrm{COOH}+\mathrm{CH}_{3} \mathrm{CH}_{2} \mathrm{OH} \\
\mathrm{CH}_{3} \mathrm{COOH}+\mathrm{CH}_{3} \mathrm{CH}_{2} \mathrm{OH} \rightarrow \mathrm{CH}_{3} \mathrm{COOCH} \mathrm{CH}_{3}+\mathrm{H}_{2} \mathrm{O} \\
\mathrm{CH}_{3} \mathrm{COOH}+\mathrm{H}_{2} \rightarrow \mathrm{CH}_{3} \mathrm{CHO}+\mathrm{H}_{2} \mathrm{O}
\end{gathered}
$$

Equation (7') is well-known as the Tishchenko reaction, and Equation (9) as the Fisher Esterification. The experimental results indicate the progress in Equation (7) instead of (7') on Ni-M41. It is already known that hydrolysis of ETA [Equation (8'), the reverse reaction of Equation (9)] gives acetic acid and $\mathrm{EtOH}$, but Equation (8) is not popular. The reverse reaction of Equation (8), however, was already confirmed to proceed catalytically and was put into practical use by Showa Denko K.K., Japan [69]. To postulate Equation (8) is therefore legitimate. The sequence of reactions (6)-(7)-(8)-(9)-(8) would result in the formation of $\mathrm{C}_{2}{ }^{-}$from $\mathrm{AAD}$ and $\mathrm{EtOH}$ through ETA and acetic acid as the intermediates.

\subsection{Characterization of Nickel Species Loaded on the Mesoporous Silica}

Three kinds of Ni-loaded M41 samples were prepared to clarify the state of the nickel ion. They were prepared by TIE, impregnation (IMP), equilibrium adsorption (EA) of $\left[\mathrm{Ni}_{(}\left(\mathrm{NH}_{3}\right)_{\mathrm{x}}\right]^{2+}$ as shown later. The colors of the EA, TIE and IMP catalysts were pale ivory, pale ivory and pale blackish purple, respectively. The following results and discussion will be described on the premise of no essential difference in the pore structures among the M41 samples employed here.

The activity of the TIE catalyst for the ETP reaction was first compared with those of the IMP catalysts. Figure 7 shows the catalytic activities of $\mathrm{Ni}-\mathrm{M} 41, \mathrm{Ni} / \mathrm{M} 41$, and $\mathrm{Ni} / \mathrm{SiO}_{2}$ at 1 and $4 \mathrm{~h}$ after the beginning of the reaction. Only the Ni-M41 catalyst prepared by the TIE method showed high and stable activity for the ETP reaction, while the activity of $\mathrm{Ni} / \mathrm{M} 41$ or $\mathrm{Ni} / \mathrm{SiO}_{2}$ was very low and decreased with the reaction time. To clarify the origin of the great difference between the activities of TIE- and IMP-catalysts, the catalysts were characterized by various methods. Surface areas of Ni-M41 and Ni/M41 calcined at $773 \mathrm{~K}$ were 856 and $822 \mathrm{~m}^{2} / \mathrm{g}$, respectively. The values indicate little correlation between the surface area and the catalysis. The XRD measurements did not confirm any nickel-related crystalline phases on the TIE-catalysts, but showed the formation of NiO particles on the IMP catalysts.

More detailed characterization of the supported nickel species has been carried out by using the EXAFS and TPR techniques. Figure 8 shows radial structure functions (RSFs) of Ni-ion loaded catalysts and reference compounds. Most of the samples except the Ni foil gave two peaks at $0.15-0.16$ and $0.26-0.28 \mathrm{~nm}$ though their respective intensities were depended on the samples. The latter peaks indicate the presence of Ni-Ni pairs. The conventional curve fitting analysis was applied to the spectra to determine the interatomic distance and the coordination numbers around the nickel atom and the results are summarized in Table 1. It should be noted in the table that the accuracy of coordination numbers estimated for the second coordination sphere has some uncertainty because the range of EXAFS spectra adopted here was limited to $120 \mathrm{~nm}^{-1}$. We employed $\mathrm{Ni}$ foil, $\mathrm{NiO}$, and two kinds of layered nickel silicates as the reference compounds. 
Figure 7. Catalytic activity of nickel-ion loaded catalysts for the ETP reaction at $673 \mathrm{~K}$. The reaction times after the beginning of the reaction are described in the parentheses. Catalysts: Ni-M41, Ni/M41, Ni/SiO $2, \mathrm{Ni}_{-} \mathrm{NH}_{3} / \mathrm{M} 41$, and $\mathrm{Ni}-\mathrm{NH}_{3} / \mathrm{SiO}_{2}$. Catalyst $0.3 \mathrm{~g}$, total flow rate $11 \mathrm{~mL} / \mathrm{min}, 0.1 \mathrm{MPa}$, ethene $9.3 \%$ and water $1.4 \%\left(\mathrm{~N}_{2}\right.$ balance $)$. Alkanes: methane and ethane.

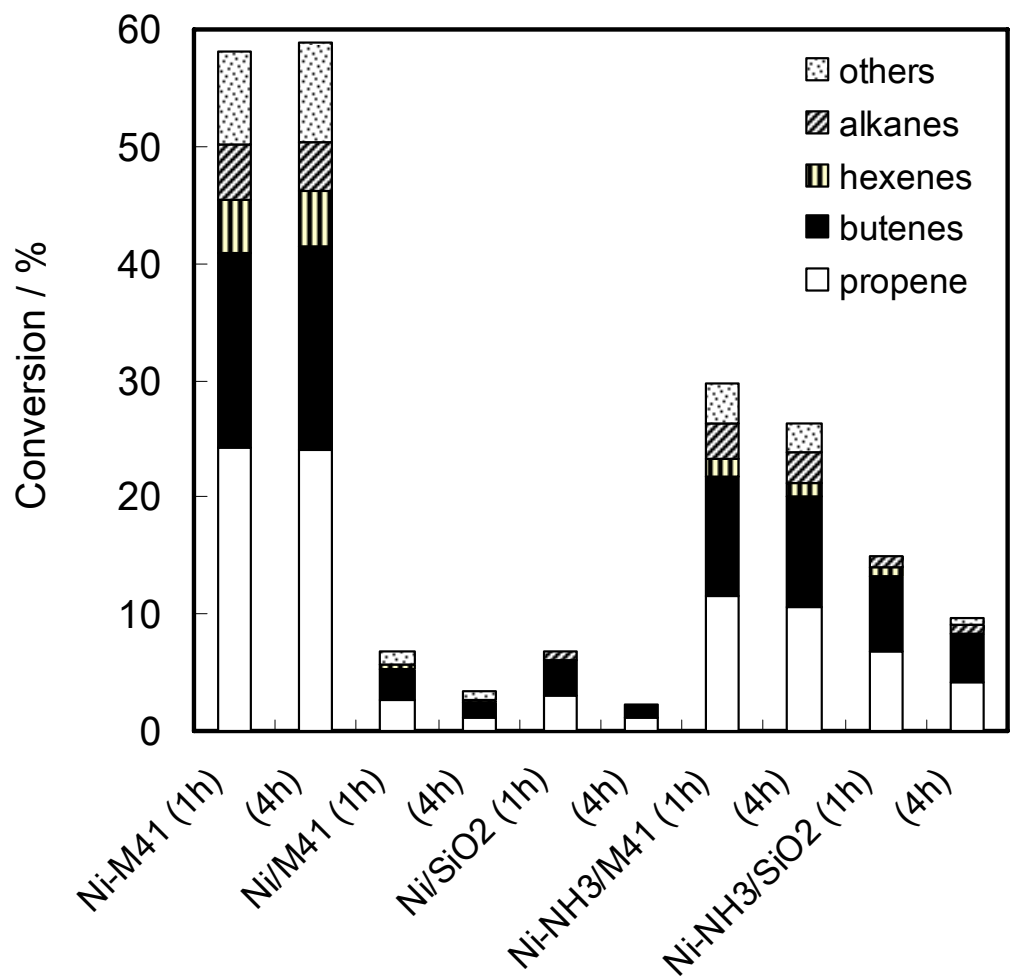

Table 1. XAFS parameters of $\mathrm{Ni}$ ion in various Ni-loaded silica catalysts.

\begin{tabular}{|c|c|c|c|c|c|}
\hline Sample & Shell & C. $\mathbf{N}^{\mathrm{a}}$ & $\mathrm{D} / \mathbf{n m}^{\mathrm{b}}$ & $\Delta \sigma^{2} / \mathbf{n m}^{2} \mathbf{c}$ & $R / \%^{d}$ \\
\hline \multirow[t]{3}{*}{ Ni-M41 } & $\mathrm{Ni}-\mathrm{O}$ & 6.9 & 0.208 & $6.08 \times 10^{-5}$ & 16.2 \\
\hline & $\mathrm{Ni}-\mathrm{Ni}$ & 5.1 & 0.305 & $4.90 \times 10^{-5}$ & 4.4 \\
\hline & $\mathrm{Ni}-\mathrm{Si}$ & 2.0 & 0.336 & $1.02 \times 10^{-5}$ & \\
\hline \multirow[t]{2}{*}{$\mathrm{Ni} / \mathrm{M} 41$} & $\mathrm{Ni}-\mathrm{O}$ & $\mathrm{f}$ & & & \\
\hline & $\mathrm{Ni}-\mathrm{Ni}$ & 10.3 & 0.300 & $5.04 \times 10^{-5}$ & 3.0 \\
\hline \multirow[t]{2}{*}{$\mathrm{Ni} / \mathrm{SiO}_{2}$} & $\mathrm{Ni}-\mathrm{O}$ & $\mathrm{f}$ & & & \\
\hline & $\mathrm{Ni}-\mathrm{Ni}$ & 11.6 & 0.296 & $3.84 \times 10^{-5}$ & 1.3 \\
\hline \multirow[t]{3}{*}{$\mathrm{Ni}-\mathrm{NH}_{3} / \mathrm{M} 41$} & $\mathrm{Ni}-\mathrm{O}$ & $\mathrm{ff}$ & & & \\
\hline & $\mathrm{Ni}-\mathrm{Ni}$ & 3.8 & 0.305 & $3.25 \times 10^{-5}$ & 6.1 \\
\hline & $\mathrm{Ni}-\mathrm{Si}$ & 2.4 & 0.337 & $0.6 \times 10^{-5}$ & \\
\hline \multirow[t]{2}{*}{$\mathrm{NiO}$} & $\mathrm{Ni}-\mathrm{O}$ & 6 & 0.208 & & \\
\hline & $\mathrm{Ni}-\mathrm{Ni}$ & 12 & 0.295 & & \\
\hline \multirow[t]{2}{*}{ Ni-talcite ${ }^{\mathrm{e}}$} & $\mathrm{Ni}-\mathrm{Ni}$ & 6.0 & 0.305 & & \\
\hline & $\mathrm{Ni}-\mathrm{Si}$ & 5.0 & 0.327 & & \\
\hline \multirow[t]{2}{*}{ Nepouite $^{\mathrm{e}}$} & $\mathrm{Ni}-\mathrm{Ni}$ & 6.0 & 0.309 & & \\
\hline & $\mathrm{Ni}-\mathrm{Si}$ & 2.4 & 0.327 & & \\
\hline
\end{tabular}

${ }^{a}$ Coordination number; ${ }^{b}$ Interatomic distance; ${ }^{c}$ Debye Waller factor; ${ }^{d}$ Agreement factor;

${ }^{\mathrm{e}}$ Cited from reference [70]; ${ }^{\mathrm{f}}$ No appropriate fits could be obtained. 
Figure 8. Fourier transforms of $k^{3}$-weighted EXAFS spectra of (a) Ni-M41; (b) Ni/M41; (c) $\mathrm{Ni} / \mathrm{SiO}_{2}$; (d) $\mathrm{Ni}-\mathrm{NH}_{3} / \mathrm{M} 41$; (e) $\mathrm{Ni}-\mathrm{NH}_{3} / \mathrm{SiO}_{2}$; (f) $\mathrm{Ni}$ foil; (g) $\mathrm{NiO}$; (h) Ni-silicate (antigorite); and (i) Ni-silicate (talcite). $\Delta k: 3.2-12 \AA^{-1}$.

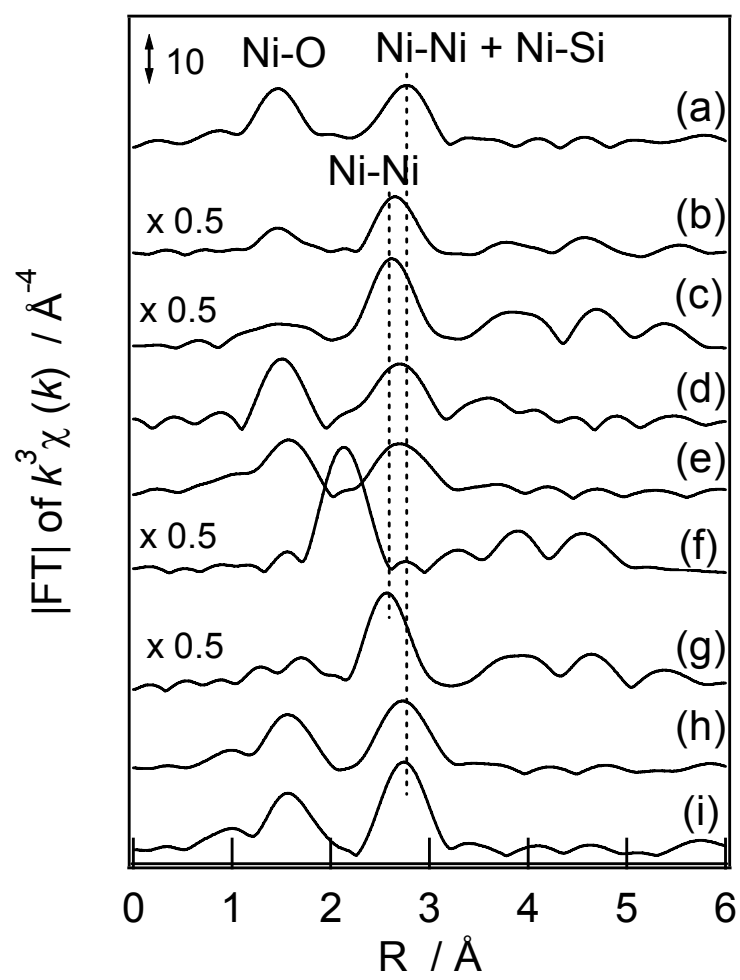

Table 1 and Figure 8 reveal several important points from the comparison with the literature [70-80]. The distance and the coordination number of the first shells (oxygen backscatterer) on Ni-M41 indicate the presence of hexacoordinated $\mathrm{Ni}^{2+} 6 \mathrm{c}$ ions [71] in the TIE sample. Yang et al. [72] reported that the nickel ion substituted for Si ion in the M41 framework has a tetrahedral coordination structure, which indicates a complete difference between the coordination states of the nickel ions in the present TIE sample and in the Ni-MCM-41 prepared by the sol-gel method. The distances of the second shell (Ni and Si backscatterer) of Ni-M41, 0.305 and $0.336 \mathrm{~nm}$, were longer than those of $\mathrm{NiO}$ and Ni/M41, and similar to those of layered nickel silicates. The findings concerning the first and second shells strongly indicate that the nickel ion in the TIE sample has a layered nickel silicate-like structure. The typical layered nickel silicates consist of a $\mathrm{NiO}_{6}$ layer sandwiched by one or two silica layers $[70,73,74,81,82]$. The EXAFS spectra of the two types of nickel silicates [Table 1 and Figures $8 \mathrm{~h}, \mathrm{i}$ ], however, were quite similar to each other, as has already been reported by several workers [70,71,75]. At the moment therefore we cannot determine the exact surface structure of nickel ion on the basis of the EXAFS spectra. In contrast, the $\mathrm{Ni} / \mathrm{M} 41$ and $\mathrm{Ni} / \mathrm{SiO}_{2}$ catalysts gave spectra assignable to $\mathrm{NiO}$ species because the Ni-Ni distance was shorter than those of Ni-M41 and the layered-nickel silicates. It follows that the preparation methods have an essential effect for the appearance of the catalytic activity through the change in loading states of nickel ion on the supports. The role of layered-nickel silicates on M41 for the catalysis will be described in the later paragraphs in more detail.

The nickel species in the TIE catalyst gave a reduction peak at $931 \mathrm{~K}$ in the TPR experiments. This temperature was much higher than those of $\mathrm{Ni} / \mathrm{M} 41(839 \mathrm{~K}), \mathrm{Ni} / \mathrm{SiO}_{2}(746 \mathrm{~K})$, and $\mathrm{NiO}$ alone $(673 \mathrm{~K})$. In TPR profiles of the nickel silicates, similar to previous works $[74,76]$, the broad 
reduction peaks were observed on these samples. On the basis of many TPR experiments reported so far $[72,79,83,84]$, we can summarize the TPR peak regions of nickel on silica as follows: Ni-oxide, the cationic form of nickel on the silica surface, and the nickel ion forming some surface composite compounds could be reduced at ca. 600-800, 800-900, and 900-1,000 K, respectively. The reduction temperature of Ni-M41 clearly falls within the region of the reduction of composite compounds. This further supports the above conclusion that the nickel ion in the TIE sample might form the layered nickel silicate like-structure on the surface.

The amounts of $\mathrm{H}_{2}$ consumed in the TPR experiments of the TIE sample and the layered silicates were almost equal to those of nickel ion contained in the respective samples. In contrast, the IMP catalysts gave a much higher ratio than unity. The composition of $\mathrm{Ni}$ oxide prepared by thermal decomposition of nickel carbonate at $773 \mathrm{~K}$ was reported to be $\mathrm{NiO}_{1.13}$ and its color was black [85]. In addition, Ni-oxide prepared by the impregnation onto silica support was suggested to be most probable $\mathrm{Ni}_{2} \mathrm{O}_{3}$ species [84]. The larger TPR peaks than those expected from $\mathrm{H}_{2} / \mathrm{Ni}=1$ and the pale blackish purple color of the present IMP catalysts both indicate the existence of the mixture of $\mathrm{Ni}_{2} \mathrm{O}_{3}$ and $\mathrm{NiO}$ on the silica surface.

The surface layered nickel silicate is reported to be produced by loading of nickel ion as amine-complexes onto silica in a basic aqueous solution and then heating them in air at $623-1,073 \mathrm{~K}$ $[71,72,76,78-80,83,86,87]$. Hadjiivanov et al. reported that the EA of $\left[\mathrm{Ni}\left(\mathrm{NH}_{3}\right)_{\mathrm{x}}\right]^{2+}$ onto silica gel at $\mathrm{pH}$ 12.3 and the subsequent calcination at $623 \mathrm{~K}$ is effective for its preparation with ease [83]. We have here applied their method to prepare the samples containing the surface layered nickel silicate (the EA catalysts) to evaluate its role for the catalysis, in which the EA samples were finally calcined at $773 \mathrm{~K}$. The XRD patterns of the Ni-NH$/ \mathrm{M} 41$ and $\mathrm{Ni}-\mathrm{NH}_{3} / \mathrm{SiO}_{2}$ catalysts did not show any diffraction peaks assignable to the layered nickel silicate, indicating the domain size of the surface layered nickel silicate was not large. The fine structure of nickel ion in the EA catalyst was studied by XAFS and the results are shown in Figure 8 and Table 1. It is clear that the spectra were very similar to those of the layered nickel silicate. The TPR profiles of the EA catalysts were separately measured. They have much resemblance to that of Ni-M41 though the reduction temperatures, 898 and $927 \mathrm{~K}$, were somewhat lower than that of Ni-M41. All of the results clearly indicate the formation of the layered nickel silicate on the silica surface by the EA method, as has been reported by several authors.

The catalytic activity of the $\mathrm{Ni}-\mathrm{NH}_{3} / \mathrm{M} 41$ and $\mathrm{Ni}-\mathrm{NH}_{3} / \mathrm{SiO}_{2}$ samples is shown in Figure 7 . It was lower than that of the Ni-M41 sample (the TIE catalyst) while much greater than those of the IMP samples. Deactivation during the reaction was also observed with the EA samples, but the degrees were smaller than those of the IMP catalysts. More detailed investigation into the preparation conditions of the EA catalysts possibly leads to raising their catalytic activity to the same levels as that of the TIE catalyst. This estimation was indeed realized partly by Lehman et al. [88] All results presented here showed that the TIE method is the most effective to prepare the active nickel ion-loaded catalysts and the high catalytic activity would result from the effective formation of surface layered nickel silicate-like structure. It would be worth to note that we attempted to measure the dispersion of nickel metal on the TIE samples after the TPR experiments by the conventional CO adsorption [89,90] but we could not find any irreversible adsorption of CO. This means that the state of nickel metal on the TIE catalysts is entirely different from those on the conventional catalysts, which would be a target for the future study. 


\section{Experimental Section}

M41 was prepared in the reported procedure [91-93] using $\mathrm{C}_{12} \mathrm{H}_{25} \mathrm{~N}\left(\mathrm{CH}_{3}\right)_{3} \mathrm{Br}$ as the template and colloidal silica as the silica source. Nickel ion was loaded onto M41 by the template ion exchange (TIE) method using an aqueous nickel nitrate solution [49,50,91-93], the conventional impregnation method, or the equilibrium adsorption method, as will be summarized in Section 3.3. The samples were named as Ni-M41, Ni/M41, and Ni-NH$/$ M41, respectively. As-prepared Ni-loaded MCM-41 was calcined at $773 \mathrm{~K}$ for $6 \mathrm{~h}$ in air, in which the sample was thinly (less than $2 \mathrm{~mm}$ thick) spread onto a ceramic board and heated at $0.2-0.5 \mathrm{~K}$ a minute. The slow heating with the shallow bed method was important to obtain good and reproducible catalytic activity. The Brunauer-Emmett-Teller (BET) surface area and the Barrett-Joyner-Halenda $(\mathrm{BJH})$ pore diameter determined by a $\mathrm{N}_{2}$ adsorption measurement were $873-1010 \mathrm{~m}^{2} \mathrm{~g}^{-1}$ and $2.2 \mathrm{~nm}$, respectively. The hexagonal structure of the resulting M41 was confirmed by the appearance of $2 \theta=2.580^{\circ}, 4.476^{\circ}$, and $5.124^{\circ}$ peaks in the X-ray diffraction patterns $\left(\mathrm{Cu} \mathrm{K}_{\alpha}\right.$, Ni filter), which corresponded to (100), (110), and (200), respectively. The $\mathrm{Si} / \mathrm{Ni}$ atomic ratios in the calcined samples were 23-28 unless otherwise stated (values were shown between brackets in the sample names). The $\mathrm{Si} / \mathrm{Al}$ atomic ratios were 237-243, in which the origin of Al was an impurity of the colloidal silica raw material. The catalytic reaction was carried out using a fixed-bed flow reactor at atmospheric pressure. The catalyst $(0.05-0.5 \mathrm{~g})$ was loaded in the reactor, heated in $\mathrm{N}_{2}$ at $673 \mathrm{~K}$, and then $\mathrm{C}_{2}=$ or $\mathrm{EtOH}\left(\mathrm{P}_{\mathrm{C} 2=}\right.$ or $P_{\mathrm{EtOH}}=2.8-12.8 \mathrm{kPa}, \mathrm{N}_{2}$ balance, total flow rate

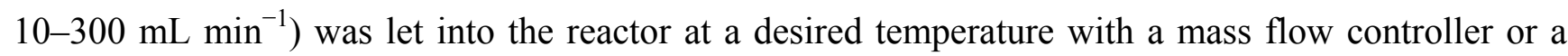
syringe-type microfeeder. The product distribution was determined by an on-line gas chromatograph and the yields and selectivity were calculated on the carbon basis.

\section{Conclusions}

Our reports have for the first time claimed the gas-phase metathesis on nickel-containing catalysts at around $673 \mathrm{~K}$. The specific characteristics of this finding are nickel, gas-phase, and high temperature. The reaction mechanism is suggested to be the dimerization of $\mathrm{C} 2{ }^{=}$, the isomerization of the produced $1-\mathrm{C} 4{ }^{=}$, and the metathesis of $\mathrm{C} 4{ }^{-}$and $\mathrm{C} 2{ }^{-}$to yield $\mathrm{C} 3^{-}$. The reaction was then expanded to ethanol and we could also get $\mathrm{C}^{-}$from EtOH. Two reaction routes for the formation of $\mathrm{C}^{-}$from $\mathrm{EtOH}$ on Ni-M41 were revealed and proceeded in parallel. One is the dehydration route via DEE as intermediate. The other is a complicated route through AAD and ETA as intermediates. The reaction rate of the latter route is slower than that of the former, since the formation of AAD was observed in a wide range of $\mathrm{SV}$ values. The $\mathrm{C} 2{ }^{=}$produced was converted to $\mathrm{C} 3^{-}$through dimerization, isomerization, and metathesis. The present results indicate that the formation of $\mathrm{C}^{-}$from $\mathrm{C} 2{ }^{=}$or EtOH could be achieved by not using the shape selectivity well known in zeolite catalysis. The layered nickel-silicate like structure would be the active species for the new type of ETP reaction. More detailed investigation of the present system would develop a new horizon in gas-phase metathesis.

\section{Acknowledgments}

The author is deeply grateful to Professor Emeritus Atsumu Ozaki of Tokyo Institute of Technology for his fruitful discussions and also to Mrs. Osamu Takahashi, Hiroshi Ohashi, Takahiro Kakinuma, 
and Tetsuo Suzuki of the NEDO research group for their helpful discussion. This work was financially supported by three Grants-in-Aids (JSPS, NEDO, and ALCA) from the Ministries, MEXT and METI of Japan.

\section{References}

1. Arpe, H.J. Industrial Organic Chemistry, 4th ed.; Wiley-VCH Verlag BmbH \& Co.: Weinheim, Germany, 2003.

2. Olah, G.A.; Molnar, A. Hydrocarbon Chemistry, 2nd ed.; John Wiley \& Sons, Inc.: Hoboken, NJ, USA, 2003; Volume 30.

3. Banks, R.L.; Kukes, S.G. New developments and concepts in enhancing activities of heterogeneous metathesis catalysts. J. Mol. Catal. 1985, 28, 117-131.

4. O’Nill, P.P.; Rooney, J.J. Direct transformation of ethylene to propylene on an olefin metathesis catalyst. J. Am. Chem. Soc. 1972, 94, 4383-4384.

5. Yamaguchi, T.; Tanaka, Y.; Tanabe, K. Isomerization and disproportionation of olefins over tungsten oxides supported on various oxides. J. Catal. 1980, 65, 442-447.

6. Lu, J.; Zhao, Z.; Xu, C.; Duan, A.; Zhang, P. CrHZSM-5 Zeolites - Highly Efficient Catalysts for Catalytic Cracking of Isobutane to Produce Light Olefins. Catal. Lett. 2006, 109, 65-70 and the references therein.

7. Oikawa, H.; Shibata, Y.; Baba, T. Highly selective conversion of ethene to propene over SAPO34 as a solid acid catalyst. Appl. Catal. A Gen. 2006, 312, 181-185.

8. Speiser, F.; Braunstein, P.; Saussine, L. Catalytic Ethylene Dimerization and Oligomerization: Recent Developments with Nickel Complexes Containing P,N-Chelating Ligands. Acc. Chem. Res. 2005, 38, 784-793 and the references therein.

9. Shiba, T.; Ozaki, A. A catalyst consisting of nickel oxide and silica. I. The catalytic activity of ethylene polymerization caused by vacuum heating. Nippon Kagaku Zasshi 1953, 74, 295-297.

10. Ozaki, A. Mixed catalyst composed of nickel oxide and silica. V. Relation between the composition and the activity for the polymerization of ethylene. Nippon Kagaku Zasshi 1956, 77, 888-892.

11. Kimura, K.; Ai, H.; Ozaki, A. Tracer study of ethylene dimerization over nickel oxide-silica catalyst. J. Catal. 1970, 18, 271-280.

12. Sohn, J.R.; Ozaki, A. Acidity of nickel silicate and its bearing on the catalytic activity for ethylene dimerization and butene isomerization. J. Catal. 1980, 61, 29-38.

13. Ghosh, A.K.; Kevan, L. Electron spin resonance studies of ethylene dimerization catalyzed by nickel species on Y zeolites. J. Phys. Chem. 1990, 94, 3117-3121.

14. Zheng, L.; Wang, G.; Bai, X. Interaction of nickel ions with ethylene molecules in ethylene dimerization over Ni-X zeolites. Stud. Surf. Sci. Catal. 1986, 28, 965-972.

15. Hertmann, M.; Poppl, A.; Kevan, L. Ethylene Dimerization and Butene Isomerization in NickelContaining MCM-41 and AlMCM-41 Mesoporous Molecular Sieves: An Electron Spin Resonance and Gas Chromatography Study. J. Phys. Chem. 1996, 100, 9906-9910. 
16. Iwamoto, M.; Tanaka, Y.; Sawamura, N.; Namba, S. Remarkable Effect of Pore Size on the Catalytic Activity of Mesoporous Silica for the Acetalization of Cyclohexanone with Methanol. J. Am. Chem. Soc. 2003, 125, 13032-13033.

17. Tanaka, Y.; Sawamura, N.; Iwamoto, M. Highly effective acetalization of aldehydes and ketones with methanol on siliceous mesoporous material. Tetrahedron Lett. 1998, 39, 9457-9460.

18. Ishitani, H.; Iwamoto, M. Selective aldol reactions of acetals on mesoporous silica catalyst. Tetrahedron Lett. 2003, 44, 299-301.

19. Murata, H.; Ishitani, H.; Iwamoto, M. Synthesis of Biginelli dihydropyrimidinone derivatives with various substituents on aluminium-planted mesoporous silica catalyst. Org. Biomol. Chem. 2010, 8, 1202-1211.

20. Murata, H.; Ishitani, H.; Iwamoto, M. Highly ordered aluminum-planted mesoporous silica as active catalyst for Biginelli reaction and formyl $\mathrm{C}-\mathrm{H}$ insertion reaction with diazo ester. Phys. Chem. Chem. Phys. 2010, 12, 14452-14455.

21. Trong, D.; Joshi, P.N.; Lemay, G.; Kaliaguine, S. Acidity and structural state of boron in mesoporous boron silicate MCM-41. Stud. Surf. Sci. Catal. 1995, 97, 543-549.

22. Yamamoto, T.; Tanaka, T.; Funabiki, T.; Yoshida, S. Acidic Property of FSM-16. J. Phys. Chem. $B$ 1998, 102, 5830-5839.

23. Ito, A.; Kodama, T.; Maeda, S.; Masaki, Y. Selective acceleration for deprotection of benzyl ethers with Ti-HMS. Tetrahedron Lett. 1998, 39, 9461-9464.

24. Phillips, C.B.; Datta, R. Production of Ethylene from Hydrous Ethanol on H-ZSM-5 under Mild Conditions. Ind. Eng. Chem. Res. 1997, 36, 4466-4475.

25. Brando, P.; Philippou, A.; Rocha, J.; Anderson, M.W. Dehydration of Alcohols by Microporous Niobium Silicate AM-11. Catal. Lett. 2002, 80, 99-102.

26. Aguayo, A.T.; Gayubo, A.G.; Atutxa, A.; Olazar, M.; Bilbao, J. Catalyst Deactivation by Coke in the Transformation of Aqueous Ethanol into Hydrocarbons. Kinetic Modeling and Acidity Deterioration of the Catalyst. Ind. Eng. Chem. Res. 2002, 41, 4216-4224.

27. Aguayo, A.T.; Gayubo, A.G.; Tarro, A.M.; Atutxa, A.; Bilbao, J. Study of operating variables in the transformation of aqueous ethanol into hydrocarbons on an HZSM-5 zeolite. J. Chem. Technol. Biotechnol. 2002, 77, 211-216.

28. Gayubo, A.G.; Alonso, A.; Valle, B.; Aguayo, A.T.; Bilbao, J. Kinetic Model for the Transformation of Bioethanol into Olefins over a HZSM-5 Zeolite Treated with Alkali. Ind. Eng. Chem. Res. 2010, 49, 10836-10844.

29. Gayubo, A.G.; Alonso, A.; Valle, B.; Aguayo, A.T.; Olazar, M.; Bilbao, J. Kinetic modelling for the transformation of bioethanol into olefins on a hydrothermally stable Ni-HZSM-5 catalyst considering the deactivation by coke. Chem. Eng. J. 2011, 167, 262-277.

30. Takahara, I.; Saito, M.; Inaba, M.; Murata, K. Dehydration of Ethanol into Ethylene over Solid Acid Catalysts. Catal. Lett. 2005, 105, 249-252.

31. Takahara, I.; Saito, M.; Matsuhasi, H.; Inaba, M.; Murata, K. Increase in the number of acid sites of a H-ZSM 5 zeolite during the dehydration of ethanol. Catal. Lett. 2007, 113, 82-85.

32. Inaba, M.; Murata, K.; Saito, M.; Takahara, I. Production of olefins from ethanol by Fe-supported zeolite catalysts. Green Chem. 2007, 9, 638-646. 
33. Song, Z.; Takahashi, A.; Mimura, N.; Fujitani, T. Production of Propylene from Ethanol Over ZSM-5 Zeolites. Catal. Lett. 2009, 131, 364-369.

34. Song, Z.; Takahashi, A.; Nakamura, I.; Fujitani, T. Phosphorus-modified ZSM-5 for conversion of ethanol to propylene. Appl. Catal. A Gen. 2010, 384, 201-205.

35. Arias, D.; Colmenares, A.; Cubeiro, M.L.; Goldwasser, J.; Lopez, C.M.; Machado, F.J.; Sazo, V. The transformation of ethanol over AlPO4 and SAPO molecular sieves with AEL and AFI topology. Kinetic and thermodynamic approach. Catal. Lett. 1997, 45, 51-58.

36. Golay, S.; Doepper, R.; Renken, A. Reactor performance enhancement under periodic operation for the ethanol dehydration over $\gamma$-alumina, a reaction with a stop-effect. Chem. Eng. Sci. 1999, 54, 4469-4474.

37. Bakoyannakis, D.N.; Zamboulis, D.; Stalidis, G.A.; Deliyanni, E.A. The effect of preparation method on the catalytic activity of amorphous aluminas in ethanol dehydration. J. Chem. Technol. Biotechnol. 2001, 76, 1159-1164.

38. Doheim, M.M.; El-Shobaky, H.G. Catalytic conversion of ethanol and iso-propanol over ZnO-treated $\mathrm{Co}_{3} \mathrm{O}_{4} / \mathrm{Al}_{2} \mathrm{O}_{3}$ solids. Colloids Surf. A 2002, 204, 169-174.

39. Zaki, T. Catalytic dehydration of ethanol using transition metal oxide catalysts. J. Colloid Interface Sci. 2005, 284, 606-613.

40. Varisli, D.; Dogu, T.; Dogu, G. Ethylene and diethyl-ether production by dehydration reaction of ethanol over different heteropolyacid catalysts. Chem. Eng. Sci. 2007, 62, 5349-5352.

41. Varisli, D.; Dogu, T.; Dogu, G. Silicotungstic Acid Impregnated MCM-41-like Mesoporous Solid Acid Catalysts for Dehydration of Ethanol. Ind. Eng. Chem. Res. 2008, 47, 4071-4076.

42. Varisli, D.; Dogu, T.; Dogu, G. Novel Mesoporous Nanocomposite WOx-Silicate Acidic Catalysts: Ethylene and Diethylether from Ethanol. Ind. Eng. Chem. Res. 2009, 48, 9394-9401.

43. Carrasco-Marn, F.; Mueden, A.; Moreno-Castilla, C. Surface-Treated Activated Carbons as Catalysts for the Dehydration and Dehydrogenation Reactions of Ethanol. J. Phys. Chem. B 1998, 102, 9239-9244.

44. Kamiguchi, S.; Chihara, T. Catalytic Dehydration of Alcohol to Olefin and Ether by Halide Clusters of $\mathrm{Nb}$, Mo, Ta and $\mathrm{W}$ Possessing an Octahedral Metal Core. Catal. Lett. 2003, 85, 97-100.

45. Kamiguchi, S.; Nagashima, S.; Komori, K.; Kodomari, M.; Chihara, T. Thermal Activation of Molecular Tungsten Halide Clusters with the Retention of an Octahedral Metal Framework and the Catalytic Dehydration of Alcohols to Olefins as a Solid Acid Catalyst. J. Cluster Sci. 2007, 18, 414-430.

46. Kamimura, Y.; Sato, S.; Takahashi, R.; Sodesawa, T.; Akashi, T. Synthesis of 3-pentanone from 1-propanol over $\mathrm{CeO}_{2}-\mathrm{Fe}_{2} \mathrm{O}_{3}$ catalysts. Appl. Catal. A Gen. 2003, 252, 399-410.

47. Nagashima, O.; Sato, S.; Takahashi, R.; Sodesawa, T. Ketonization of carboxylic acids over CeO2-based composite oxides. J. Mol. Catal. A Chem. 2005, 227, 231-239.

48. Tsuchida, T.; Kubo, J.; Yoshioka, T.; Sakuma, S.; Takeguchi, T.; Ueda, W. Reaction of ethanol over hydroxyapatite affected by Ca/P ratio of catalyst. J. Catal. 2008, 259, 183-189.

49. Iwamoto, M.; Kosugi, Y. Highly Selective Conversion of Ethene to Propene and Butenes on Nickel Ion-Loaded Mesoporous Silica Catalysts. J. Phys. Chem. C 2007, 111, 13-15. 
50. Ikeda, K.; Kawamura, Y.; Yamamoto, T.; Iwamoto, M. Effectiveness of the template-ion exchange method for appearance of catalytic activity of Ni-MCM-41 for the ethene to propene reaction. Catal. Commun. 2008, 9, 106-110.

51. Kasai, K.; Haishi, T.; Iwamoto, M. Selective conversion of bio-ethanol to lower olefins on nickel ion-loaded mesoporous silica catalysts. Shokubai 2007, 49, 126-128.

52. Iwamoto, M.; Kasai, K. Preparation of olefins from alcohols by use of ordered mesoporous catalysts in high yield. Jpn. Tokkyo Koho 2008, JP 2008255104 A 20081023.

53. Haishi, T.; Kasai, K.; Iwamoto, M. Fast and Quantitative Dehydration of Lower Alcohols to Corresponding Olefins on Mesoporous Silica Catalyst. Chem. Lett. 2011, 40, 614-616.

54. Iwamoto, M.; Kasai, K.; Haishi, T. Conversion of Ethanol into Polyolefin Building Blocks: Reaction Pathways on Nickel Ion-loaded Mesoporous Silica. ChemSusChem 2011, 4, 1055-1058.

55. Sugiyama, S.; Kato, Y.; Wada, T.; Ogawa, S.; Nakagawa, K.; Sotowa, K. Ethanol Conversion on MCM-41 and FSM-16, and on Ni-Doped MCM-41 and FSM-16 Prepared without Hydrothermal Conditions. Top. Catal. 2010, 53, 550-554.

56. Liu, B.; Nakatani, H.; Terano, M. Mechanistic implications of the unprecedented transformations of ethene into propene and butene over Phillips $\mathrm{CrOx} / \mathrm{SiO} 2$ catalyst during induction period. J. Mol. Catal. A 2003, 201, 189-197.

57. Negishi, E.; Takahashi, T. Patterns of Stoichiometric and Catalytic Reactions of Organozirconium and Related Complexes of Synthetic Interest. Acc. Chem. Res. 1994, 27, 124-130.

58. Grubbs, R.H., Ed.; Handbook of Metathesis; Wiley-VCH Verlag BmbH \& Co.: Weinheim, Germany, 2003.

59. Grubbs, R.H. Olefin metathesis. Tetrahedron 2004, 60, 7117-7140.

60. Sato, Y.; Saito, N.; Mori, M. Asymmetric Cyclization of $\omega$-Formyl-1,3-dienes Catalyzed by a Zerovalent Nickel Complex in the Presence of Silanes. J. Org. Chem. 2002, 67, 9310-9317.

61. Baker, M.V.; Brown, D.H.; Skelton, B.W.; White, A.H. An investigation into alkenylfunctionalized 1,4,7-triazacyclononanes: Synthesis, metal complexation, and attempted olefin metathesis. Aust. J. Chem. 2002, 55, 655-600.

62. Xiao, S.; Meng, Z. X-ray photoelectron spectroscopy characterization of the reduction and oxidation behavior of Ni-containing HZSM-5 zeolites. J. Chem. Soc. Faraday Trans. 1994, 90, 2591-2595.

63. Schoonheydt, R.A.; Roodhooft, D. Spectroscopy of the thermal reduction of nickel(II) in the presence of hydrogen in zeolites X and Y. J. Phys. Chem. 1986, 90, 6319-6323.

64. Elev, I.V.; Shelimov, B.N.; Kazanskii, V.B. The role of nickel(1+) ions in the activity of NiCaY zeolite catalysts for ethylene dimerization. J. Catal. 1984, 89, 470-477.

65. Prakash, A.M.; Wasowicz, T.; Kevan, L. Reducibility, Location, and Adsorbate Interactions of $\mathrm{Ni}(\mathrm{I})$ Ions in $\mathrm{Ni}(\mathrm{II})$-Exchanged Silicoaluminophosphate Type 41 Studied by Electron Spin Resonance and Electron Spin Echo Modulation Spectroscopies. J. Phys. Chem. 1996, 100, 15947-15953.

66. Hartmann, M.; Poppl, A.; Kevan, L. Formation and Stability of Ni(I) Ions in MCM-41 Mesoporous Molecular Sieves. J. Phys. Chem. 1995, 99, 17494-17496. 
67. Taoufik, M.; Le Roux, E.; Thivolle-Cazat, J.; Basset, J.M. Direct transformation of ethylene into propylene catalyzed by a tungsten hydride supported on alumina: trifunctional single-site catalysis. Angew. Chem. Int. Ed. 2007, 46, 7202-7205.

68. Lin, B.; Zhang, Q.; Wang, Y. Catalytic Conversion of Ethylene to Propylene and Butenes over H-ZSM-5. Ind. Eng. Chem. Res. 2009, 48, 10788-10795.

69. Tsuji, K.; Uchida, H.; Nakajou, T.; Sano, K. Development of Novel Production Processes for Ethyl Acetate and Acetic Acid Catalyzed by Solid Heteropolyacids. Chem. Chem. Ind. 2008, 61, 206-208.

70. Clause, O.; Kermarec, M.; Bonneviot, L.; Villain, F.; Che, M. Nickel(II) ion-support interactions as a function of preparation method of silica-supported nickel materials. J. Am. Chem. Soc. 1992, 114, 4709-4717.

71. Carriat, J.Y.; Che, M.; Kermarec, M.; Verdaguer, M.; Michalowicz, A. Control of Dispersion of $\mathrm{Ni}^{2+}$ Ions via Chelate Ligands in the Preparation of $\mathrm{Ni} / \mathrm{SiO}_{2}$ Materials. A XAFS Study. J. Am. Chem. Soc. 1998, 120, 2059-2070.

72. Yang, Y.; Lim, S.; Du, G.; Chen, Y.; Ciuparu, D.; Haller, G.L. Synthesis and Characterization of Highly Ordered Ni-MCM-41 Mesoporous Molecular Sieves. J. Phys. Chem. B 2005, 109, 13237-13246.

73. Martin, G.A.; Renoupre, A.; Dalmaiim, G.; Imelik, B. Synthesis of nickel talc and antigorite. Study of their thermal decomposition and reduction to obtain nickel catalysts on silica. J. Chim. Phys. 1970, 67, 1149-1160.

74. Wells, A.F. Structural Inorganic Chemistry; Clarendon Press: Oxford, UK, 1984; Volume 1024.

75. Farges, F.; Munoz, M.; Siewert, R.; Malavergne, V.; Brown, G.E.; Behrens, H.; Nowak, M.; Petit, P.E. Transition elements in water-bearing silicate glasses/melts. Part II. Ni in water-bearing glasses. Geochim. Cosmochim. Acta 2001, 65, 1679-1693.

76. Burattin, P.; Che, M.; Louis, C. Characterization of the Ni(II) Phase Formed on Silica Upon Deposition-Precipitation. J. Phys. Chem. B 1997, 101, 7060-7074.

77. Yang, J.C.; Shul, Y.G.; Louis, C.; Che, M. In situ EXAFS study of the nucleation and crystal growth of $\mathrm{Ni}$ particles on $\mathrm{SiO}_{2}$ support. Catal. Today 1998, 44, 315-325.

78. Bonneviot, L.; Clause, O.; Che, M.; Manceau, A.; Decarreau, A.; Villian, F.; Bazin, D.; Dexpert, $\mathrm{H}$. Investigation by EXAFS of the effect of $\mathrm{pH}$ on the structure of nickel $(2+)$ ions impregnated on silica. Phys. B 1989, 158, 43-44.

79. Clause, O.; Bonneviot, L.; Che, M.; Dexpert, H. EXAFS characterization of the adsorbed state of nickel(II) ions in nickel/silica materials prepared by deposition-precipitation. J. Catal. 1991, 130, 21-28.

80. Espinos, J.P.; Gonzalez-Elipe, A.R.; Munuera, G.; Garcia, J.; Conesa, J.C.; Burattini, E. EXAFS study of catalyst preparation procedure in nickel-silica and nickel-titania. Phys. B 1989, 158, 174-175.

81. Grauby, O.; Petit, S.; Decarreau, A.; Baronenet, A. The beidellite-saponite series: An experimental approach. Eur. J. Mineral. 1993, 5, 623-635.

82. Decarreau, A. Partitioning of divalent transition elements between octahedral sheets of trioctahedral smectites and water. Geochim. Cosmochim. Acta 1985, 49, 1537-1544. 
83. Hadjiivanov, K.; Mihaylov, M.; Klissurski, D.; Stefanov, P.; Abadjieva, N.; Vassileva, E.; Mintchev, L. Characterization of $\mathrm{Ni} / \mathrm{SiO}_{2}$ Catalysts Prepared by Successive Deposition and Reduction of $\mathrm{Ni}^{2+}$ Ions. J. Catal. 1999, 185, 314-323.

84. Wojcieszak, R.; Moteverdi, S.; Mercy, M.; Nowak, I.; Ziolek, M.; Bettahar, M.M. Nickel containing MCM-41 and AlMCM-41 mesoporous molecular sieves. Characteristics and activity in the hydrogenation of benzene. Appl. Catal. A Gen. 2004, 268, 241-253.

85. Kutseva, L.N. Influence of superstoichiometric oxygen on the catalytic, adsorptive, and electrical properties of nickelous oxide. Dokl. Akad. Nauk. SSSR 1961, 138, 409-411.

86. Houalla, M.; Delannay, F.; Matsuura, I.; Delmon, B. Physico-chemical characterization of impregnated and ion-exchanged silica-supported nickel oxide. J. Chem. Soc. Faraday. Trans. 1 1980, 76, 2128-2141.

87. Kermarec, M.; Carriat, J.Y.; Burattin, P.; Che, M.; Decarreau, A. FTIR Identification of the Supported Phases Produced in the Preparation of Silica-Supported Nickel Catalysts. J. Phys. Chem. 1994, 98, 12007-12017.

88. Lehmann, T.; Wolff, T.; Zahn, V.M.; Veit, P.; Hamel, C.; Seidel-Morgenstern A. Preparation of Ni-MCM-41 by equilibrium adsorption - Catalytic evaluation for the direct conversion of ethene to propene. Catal. Commun. 2011, 12, 368-374.

89. $\mathrm{Xu}, \mathrm{S}$.; Wang, $\mathrm{X}$. Highly active and coking resistant $\mathrm{Ni} / \mathrm{CeO}_{2}-\mathrm{ZrO}_{2}$ catalyst for partial oxidation of methane. Fuel 2005, 84, 563.

90. Li, G.; Hu, L.; Hill, J.M. Comparison of reducibility and stability of alumina-supported Ni catalysts prepared by impregnation and co-precipitation. Appl. Catal. A 2006, 301, 16-24.

91. Abe, T.; Tachibana, Y.; Uematsu, T.; Iwamoto, M. Preparation and characterization of Fe2O3 nanoparticles in mesoporous silicate J. Chem. Soc. Chem. Commun. 1995, 1617-1618.

92. Iwamoto, M.; Tanaka, Y. Preparation of metal ion-planted mesoporous silica by template ion-exchange method and its catalytic activity for asymmetric oxidation of sulfide. Catal. Surv. Jpn. 2001, 5, 25-36.

93. Hayashi, F.; Iwamoto, M. Effect of pore structure on the nitridation of mesoporous silica with ammonia. Eur. J. Inorg. Chem. 2010, 15, 2235-2243.

Sample Availability: No sample of the compounds is available from the author.

(C) 2011 by the authors; licensee MDPI, Basel, Switzerland. This article is an open access article distributed under the terms and conditions of the Creative Commons Attribution license (http://creativecommons.org/licenses/by/3.0/). 